\title{
Manchester's Post-punk Heritage: Mobilising and Contesting Transcultural Memory in the Context of Urban Regeneration ${ }^{1}$
}

\author{
By Dagmar Brunow
}

\begin{abstract}
Urban memories are remediated and mobilised by different - and often conflicting - stakeholders, representing the heritage industry, municipal city branding campaigns or anti-gentrification struggles. Post-punk 'retromania' (Reynolds 2011) coincided with the culture-led regeneration of former industrial cities in the Northwest of England, relaunching the cities as creative clusters (Cohen 2007, Bottà 2009, Roberts \& Cohen 2014, Roberts 2014). Drawing on my case study of the memory cultures evolving around Manchester's post-punk era (Brunow 2015), this article shows how narratives and images travel through urban space. Looking at contemporary politics of city branding, it examines the power relations involved in adapting (white homosocial) post-punk memories into the self-fashioning of Manchester as a creative city. Situated at the interface of memory studies and film studies, this article offers an anti-essentialist approach to the notion of 'transcultural memory. Examining the power relations involved in the construction of audiovisual memories, this article argues that subcultural or popular memories are not emancipatory per se, but can easily tie into neoliberal politics. Moreover, there has been a tendency to sideline or overlook feminist and queer as well as Black and Asian British contributions to post-punk culture. Only partially have such marginalised narratives been observed so far, for instance in Carol Morley's documentary The Alcohol Years (2000) or by the Manchester Digital Music Archive. The article illustrates how different stakeholders invest in subcultural histories, sustaining or contesting hegemonic power relations within memory culture. While being remediated within various transmedia contexts, Manchester's postpunk memories have been sanitised, fabricating consensus instead of celebrating difference.
\end{abstract}

Keywords: Manchester, urban reconstruction, cultural memory, transcultural memory, post-punk, Carol Morley

Brunow, Dagmar: "Manchester Post-punk heritage: Mobilising and Contesting Transcultural Memory in the Context of Urban Regenration", Culture Unbound, Volume 11, issue 1, 2019: 9-29. Published by Linköping University Electronic Press: $\underline{h t t p: / / w w w . c u l t u r e u n b o u n d . e p . l i u . s e ~}$ 


\section{Introduction}

The memory boom around the 40th anniversary of punk in 2016 is far from being a new phenomenon: for more than two decades we have been observing an incessant flow of books, memoirs, documentaries, band reunions, exhibitions or YouTube clips on punk or post-punk culture. Despite the mobility of memory, the city of Manchester has become somewhat of a 'memory hub', especially around post-punk memories of the late 1970s to the early 1980s. Post-punk 'retromania' (Reynolds 2011) coincided with the culture-led redevelopment of former industrial cities in the Northwest of England, relaunching the cities as creative clusters (Cohen 2007, Bottà 2009, Roberts \& Cohen 2014, Roberts 2014). This article examines how the cultural memory of 1980s post-punk in Manchester has been mobilised and reworked in times of urban regeneration. The case study of Manchester allows me to revisit and reconceptualise two concepts which are useful for memory studies: remediation and transculturality.

Memory studies look at the ways the past informs the present. Situated at the interface of film studies and memory studies and based on the idea that memory is always mediated my research is part of the new burgeoning field of media memory studies. Recent theorisations within memory studies have conceptualised memory as inherently transnational (DeCesari \& Rigney 2014), multi-directional (Rothberg 2009) and on the move (Erll 2011). Adding to these, I understand the construction of cultural memory as highly performative practice which goes beyond a mere preservation of experiences and events. Cultural memory is understood as "an activity that is productive of stories and new social relations rather than merely preservative of legacies" (DeCesari \& Rigney 2014: 8). This is why cultural memory needs to be conceptualised from the present, from the interest of contemporary stakeholders, all of whom are competing over the prerogative of interpretation. Memory also needs to be constantly remediated, as Astrid Erll and Ann Rigney remind us: "Just as there is no cultural memory prior to mediation, there is no mediation without remediation: all representations of the past draw on available media technologies, on existent media products, on patterns of representation and medial aesthetics" (Rigney \& Erll 2009: 4). In contrast to Jay Bolter and Robert Grusin's understanding of remediation as "the representation of one medium in another" (Bolter \& Grusin 2000: 45), Erll conceptualises it as the ongoing representation of as memorable events "over decades and centuries, in different media: in newspaper articles, photography, diaries, historiography, novels, films, etc" (Erll 2008: 392). However, the concept of remediation is neither limited to the memorialisation of events, nor to narratives or iconography, but involves the discursive context: in the process of remediation, discursive spaces for the articulation of different subject positions are opened or closed (Brunow 2015). Remediation constantly constructs and reworks our audiovisual memories, 
which I have defined as "the sum of images, sounds and narratives circulating in a specific society at a specific historical moment" (Brunow 2015: 6-7). I argue that remediation creates certain nodal points (mnemotopes) around which a number of narratives of the past are constructed. Their ongoing remediation can widen or narrow the discursive space in which they can be articulated. Studying the remediation of memories involves questions such as: Which stories, and whose, are told in the process of remediation, and what kind of stories are marginalised or remain unheard?

Memory does not belong to a specific group alone. Instead, it can be adapted, reworked and appropriated within multiple contexts. The notion of 'transculturality' can be used to refer to such different contexts. In my book Remediating Transcultural Memory I have used the case of post-punk Manchester to develop an anti-essentialist approach towards the notion of transculturality (Brunow 2015). In the wake of the 'transcultural turn' in memory studies the term "transcultural memory" is often employed to designate migrant or diasporic pasts. This tendency entails the risk of essentialising and 'othering' migrant or diasporic narratives, thereby excluding them from hegemonic national historiography. A reductive, essentialist use of the notion of 'transculturality' can also feed into nationalist discourses which understand the nation as a homogenous entity threatened by global demographic changes and which frame migration in terms of 'culture-clash' or 'cultural encounters'. This article provides an example of the use of the notion of 'transcultural memory' beyond such culturalistic discourses. Defying essentialist notions of culture(s) as "container-cultures" with clearly demarcated borders, I would like to strengthen the notion of 'culture' as inherently hybrid. Never stable and fixed, 'culture' is not ontological, but a series of practices. In this sense I conceptualise 'transcultural memory' as being translated through various discursive frameworks. This is why the notion of 'transculturality' can be a useful tool to analyse the diversity of cultural practices and the multidirectionality of memory within the same national or regional framework.

Starting with an overview of the various remediations of post-punk Manchester's (sub)cultural memory, this article aims at analysing what kind of memory is constructed in the process of ongoing remediation. It critically examines the highly gendered remediations of popular music heritage and the appropriation and reworking of subcultural memories into an official narrative. Memories are constructed, used, remediated and appropriated by different, at times competing, at times overlapping stakeholders, each of them situated in their specific sociohistorical context and not homogenous at all: fans, urban developers, city planners, tourists, to name but a few. Some of the guiding questions are: How is memory translated into different cultural contexts within the same geographical space? What are the power relations at work? Which efforts are made to reclaim the past, 
for instance by those whose memories have been overlooked? Neither offering a comprehensive account of city politics, nor an ethnological or sociological case study of urban reconstruction, this article will go beyond this and study remediation as a project of place-making, studying its role for the city's culture-led regeneration.

Examining how post-punk memories are appropriated by neoliberal politics of city branding, this article argues that the iconic spaces of post-punk Manchester are characterised by a memory culture which is predominantly heteronormative and male-oriented. This is all the more surprising since Manchester has been a traditional stronghold of LGBT+ culture for decades. Therefore, this article sets out to question notions of subcultural, popular, vernacular or other concepts of alternative memories as counter-hegemonic. This case study centres on post-punk memories of Manchester and the era of Joy Division, the Fall, the Smiths, the Haçienda (Manchester's legendary nightclub and concert venue), and the Factory label. To a lesser degree it will also consider the 'Madchester' years, a term referring to the era of rave culture at the Haçienda during the second half of the 1980s, with the advent of house, the drug culture around ecstasy and bands like the Happy Mondays, the Stone Roses or the Inspiral Carpets. ${ }^{2}$

This article is organised as follows: In the first part it takes a critical look at the memory boom and analyses "whose heritage" (Hall 2002) is celebrated in the remediation of post-punk Manchester. The second part adds an intersectional perspective on the notion of remediation, by drawing on Carol Morley's essay film The Alcohol Years (2000). This feminist intervention into the audiovisual memories of post-punk Manchester foregrounds the power relations in the construction of cultural memory. Finally, the article readdresses the notion of transcultural memory in studying how post-punk memory is translated into practices of city branding in the context of urban regeneration and gentrification. Looking at cultural practices of place-making, the last part of the article is dedicated to the discursive space allowed for the articulation of LGBT+ memories.

\section{Transcultural adaptations - between subcultural memo- ries and city branding}

Countless remediations have fashioned Manchester's local music culture in opposition to London's political and economic power. Such rhetoric can be found in many books and films on post-punk Manchester, where this scene is described as a subculture inspired by punk's do-it-yourself spirit, opposing the commercialism of London's big record labels. Meanwhile, these discourses can be likened to the characteristics of a rock museum, which, as Simon Reynolds puts it, presents "music with the battle lines erased, everything wrapped up in a warm blan- 
ket of acceptance and appreciation" (Reynolds 2011: 7). While Dick Hebdige has conceptualised subcultures as a symptom of "the breakdown of consensus in the post-war period" (Hebdige 1979/1996: 17), this consensus has been re-established in the wake of retro culture and nostalgia. For subcultural audiences a variety of independent music cultures, among them punk and post-punk, have become fundamental for their self-fashioning, for creating a sense of identity and for pronouncing their cultural distinction against commercialised mainstream culture (Thornton 1997). This sense of identity also affects the construction of cultural memory because it has repercussions on the stories individuals want to tell about their past and the cultural distinction they want to achieve through their self-fashioning. Thanks to multiple transmedia remediations of Manchester's musical heritage even later generations can inscribe themselves within the legacy of punk and post-punk. Films such as 24 Hour Party People (Winterbottom, 2002) or Anton Corbijn's Control (2007) have become integral parts of Manchester's memory culture.

Concepts of "travelling" (Erll 2011) or "multidirectional memory" (Rothberg 2009) have challenged the binary structure on which memory studies' notions of alternative memories are predicated. Memory in terms of a counter-practice has been classified as popular (Foucault 1975), counter (Lipsitz 1990) or vernacular (Bodnar 1992), for example. While the power dimension of memory and the modes of contesting hegemonic memory need to be addressed, their inherent binarism makes these concepts problematic, as they become de-historicised and de-situated. The emancipatory potential ascribed to the concept of subculture (Hebdige 1979/1996) therefore needs to be reconsidered. In fact, the notion of subculture is used here in a merely heuristic fashion, rather than pointing at a discursive formation situated within a specific context. ${ }^{3}$ My use of the term 'subculture' goes back to Dick Hebdige's seminal conceptualisation in his 1979 Subculture: the meaning of style in which he defines subculture as "expressive forms and rituals of those subordinate groups - the teddy boys and mods and rockers, the skinheads and the punks - who are alternately dismissed, denounced and canonised; treated at different times as threats to public order and as harmless buffoons" (Hebdige 1979/1996: 2). Such varying and conflicting discourses evolving around subcultures are also part of the transcultural memory of post-punk Manchester. If we agree with Hebdige that the "meaning of subculture is [...] always in dispute" (Hebdige 1979/1996: 3), the same might be the case for the memory of these subcultures.

The question remains if subcultural memories ought to be conceptualised in terms of alternative, emancipatory counter-cultures alone. Dave Haslam puts forward an understanding of (sub)cultural practice as counter-hegemonic when he describes Manchester's subculture, here epitomised in 1990s "Madchester", as a 
"culture that embraces the geographical and political margins, a pop culture long ago divorced from the dominant culture" (Haslam 1999/2000: 256). The relation between subculture, nostalgia and commodification is understood by Dylan Clarke (2003) as follows: "The classical subculture 'died' when it became the object of social inspection and nostalgia, and when it became so amenable to commodification" (Clarke 2003: 223). Since debates about the commodification of punk are almost as old as punk culture itself, I would like to turn Dylan Clarke's argument around by following Alison Landsberg (2004) who approaches the debate from a different angle: for her everything is already commodified, but some cultural practices, despite their commodification, would allow for a counter-hegemonic stand. However, the notion of counter practice has to be critically examined since its critical stand is perhaps not as far-reaching as it might seem (Brunow 2015). In short: subcultural memories are not as emancipatory as one might expect. At any rate, the formation of Manchester's cultural memory is a highly gendered process as we shall see in the next section.

\section{Whose heritage? Remediating 1980s post-punk Man- chester and its gendered dimensions}

For the last two decades a veritable memory boom can be observed around 1970s punk and 1980s post-punk in Britain. ${ }^{4}$ Some of the earliest accounts of Manchester's post-punk memory have been Mick Middles' From Joy Division to New Order in 1996 (Middles 1996/2002, re-issued as Factory. The Story of the Record Label in 2009) as well as Dave Haslam's 1999 Manchester England (Haslam 1999/2000). Michael Winterbottom's film 24 Hour Party People (2002) was accompanied by the book publication 24 Hour Party People: What the Sleeve Notes Never Tell You, authored by Tony Wilson (Wilson 2002). Deborah Curtis' Touching from a Distance (Curtis 2005), a memoir of the author's life with Joy Division singer Ian Curtis, was adapted into Anton Corbijn's Control (2007). Joy Division and Ian Curtis were also commemorated in Joy Division. Piece by Piece by Paul Morley (2008), in Torn Apart. The Life of Ian Curtis by Mick Middles (2009), in Kevin Cummins' Joy Division (Cummins 2012) as well as in Peter Hook's Unknown Pleasures: Inside Joy Division (Hook 2013). Other publications include James Nice's Shadowplayers: The Rise and Fall of Factory Records (Nice 2010), Peter Hook's The Haçienda. How Not to Run a Club (Hook 2009), Lindsay Reade's memoir of her life with Tony Wilson: Mr Manchester and the Factory Girl (Reade 2010) as well as Kevin Cummins' Manchester (Cummins 2010). John Robb's_The North Will Rise Again: Manchester Music City (Robb 2010) is a collection of oral history accounts in the tradition of his earlier volume Punk Rock (Robb 2006). Grant Gee's documentary film Joy Division (2007), which even had a cinematic release, adds to a long list of television 
documentaries on post-punk Manchester, but also to countless remediations of live performances and television appearances now uploaded on YouTube.

This overview shows how the memory boom around post-punk Manchester has been focussing increasingly on nodal points such as Joy Division (the band), Factory Records (the label) and The Haçienda (the club), most notably in films such as 24 Hour Party People by Michael Winterbottom and Anton Corbijn's Control. ${ }^{5}$ These nodal points are perpetuated by the ongoing remediation, which "tends to solidify cultural memory, creating and stabilising certain narratives and icons of the past" (Erll 2008: 393). This process in turns has repercussions on canon formation: it highlights some bands (especially Joy Division), while side-lining others (for instance the Fall or the Durutti Column). In most of the 'memory works' around 1980s Manchester the dominant narrative is defined by a homosocial (Sedgwick) and patriarchal perspective, which is white and heteronormative and in which feminist, queer or Black voices are excluded. To illustrate my point I will briefly discuss Winterbottom's 24 Hour Party People.

24 Hour Party People is a highly self-reflexive film with Brechtian moments of breaking the fourth wall, among them cameo appearances by Mark E. Smith and Howard Devoto, thus blurring the boundaries between fiction and reality. ${ }^{6}$ However, despite its self-reflexive take and playfulness 24 Hour Party People does not undermine conventional representations of gender or sexuality prevalent in pop historiography. Reducing the story of the Factory label to "a highly masculine tale of great men", as Tara Brabazon (2005: 142) observes, the film writes women "into the familiar roles of wives, girlfriends, prostitutes, cloakroom girls and anonymous mobile bodies in a club" (Brabazon 2005: 142). The film therefore constructs a discursive space for male homosociality, which according to Eve Kosofsky Sedgwick (1985) is not only based on the exclusion of women, but also on the premise of heterosexuality. As a consequence, LGBT+ memories have been completely erased from the cultural memory of the Haçienda in 24 Hour Party People (see Brabazon 2005: 142). The importance of gay culture at the Haçienda, both the "Gay Traitor Bar" and the gay nights at the "Flesh" club which attracted busloads of visitors from all over the North of England, is not acknowledged in the film. Although these gay clubs provided the economically challenged Haçienda with a much-needed financial contribution, gay culture is as absent as the representation of homosexual or bisexual desire. Without exception, the romantic or sexual encounters depicted in the film are either related to the male protagonists' wives and female lovers or to female sex workers. The film's omission of any queer desire strengthens both Tony Wilson's and the other characters' "heterosexual credibility" (Brabazon 2005: 142). ${ }^{7}$ My point here is not to criticise a lack of historical record or to make suggestions about the protagonists' sexual preferences, but the point is that a queer, norm-critical perspective foregrounds the modes of 
constructing cultural memory: 24 Hour Party People employs a highly gendered, heteronormative, patriarchal perspective while excluding LGBT+ narratives from the film's 'memory work'.

Remediating Manchester's cultural memory is a highly gendered process defined by homosocial bonding. As a consequence female artists, band members, DJs or clubbers have been more or less excluded from the cultural memory of post-punk. Such hegemonic gender constructions are not absent in the self-fashioning of independent culture. As Sarah Thornton has pointed out in her study on club culture, the distinction between mainstream and independent culture entails a gender dimension: "when the culture came to be positioned as truly 'mainstream' rather than just behind the times, it was feminized" (Thornton 1997: 205). While Thornton has looked at 1990s rave culture, Simon Reynolds and Joy Press (1995) have shown how punk culture - and post-punk - is based on the exclusion of femininity and the construction of a masculinity based on misogyny. As a tendency, the contribution of female artists is hidden while women generally tend to be reduced to wives or groupies. The "role of women in the male, often macho, world of rock", as Jon Savage writes in his preface to Curtis (2007: xiii), is often sidelined, even in biographies such as Deborah Curtis' Touching From a Distance (Curtis 2007) or Lindsay Reade's Mr Manchester and the Factory Girl: The Story of Tony and Lindsay Wilson (Reade 2010). The trajectory of the narrative in each book is written from the perspective of a former wife of one of the main protagonists of the Manchester's music scene. For Deborah Curtis and Lindsay Reade the discursive space of enunciation is limited. The same goes for the testimonial witnesses chosen for non-fiction books or documentary filmmaking: they, too, tend to be situated within a patriarchal, homosocial framework.

In the next section I would like to introduce Carol Morley's film The Alcohol Years which allows us to deeper reflect on the gendered dimension of memory. Morley's film offers a different perspective on Manchester's post-punk era. This early film by the director of the prize-winning Dreams of a Life (2011) and The Falling (2014) was funded by the Arts Council and had only a limited distribution before it was released on DVD in 2005. Reading The Alcohol Years through the male dominated memory boom allows us to see this work as a filmic intervention into the homosocial memory of post-punk Manchester.

\section{Reworking the gendered archive of post-punk memory: Carol Morley's essay film The Alcohol Years}

The autobiographical The Alcohol Years is based on the director's teenage past in the early 1980s when she used to spend her nights at the Haçienda in Manchester. ${ }^{8}$ Carol Morley's state of notorious drunkenness, her sexual activities as well as the 
fact that she almost married the Buzzcocks' singer Pete Shelley, but left him right before the wedding, contributed to turning her into a local myth. The film came about, long after Carol Morley had moved to London, when an old friend from Manchester told her a story he had heard about her during her teenage years. The disparity between his recollections and her own, or rather, her own amnesia about this period in her life, triggered off the idea to make a film about the memories circulating about her. A newspaper clipping of the ad Morley had put in a local Manchester newspaper is remediated at the beginning of the film: "Carol Morley Film Project. Please contact me if you knew me between 1982-1987. Box No. 348/1." During the film the director revisits friends and lovers from 1980s Manchester and makes them share their recollections of the person they used to know as "Carol Morley". Morley interviews, among others, Jesus And Mary Chain bassist Douglas Hart, Vini Reilly of The Durutti Column, promoter and Nico's former manager Alan Wise, singer-songwriter and musician Stella Grundy, Dave Haslam, Debby Turner of ToT as well as Tony Wilson, broadcaster and founder of Factory Records.

Morley's film is an original intervention into recent trends within autobiographical filmmaking: it is a confession video without a confessor and a first person film without the "I". Carol Morley is mostly absent in the film's visual representation while she is omnipresent throughout. The presence of the filmmaker is not only evoked via the narratives of the interviewees, but also through inserted photographs, scenes of re-enactment as well as through the talking heads addressing the person behind the camera. Moreover, the film undermines the modes of conventional documentary film-making by abstaining from a coherent voice-over which would evoke the impression of an "authentic" I-narrator. Although Morley constructs her alter ego as an absence, The Alcohol Years is characterised by a strong authorial agency. Therefore Carol Morley's film can also be viewed in the context of feminist body art, such as the works by Carolee Schneemann, Valie Export, Cindy Sherman or Marina Abramović. However, while these artists deliberately use their bodies as the centre of their performances, the female body in Morley's film remains a blank space. Although the film foregrounds male desire on the female body, the female protagonist is never exhibited, thus undermining an objectifying male gaze. In this sense, Morley's approach is reminiscent of Tracey Emin's installation Everyone I Have Ever Slept With 1963-1995 (1995), showing a quilted list of the people the artist has slept with. In Emin's art project the "I" remains strangely absent. Morley's film can be said to engage in a dialogue with Emin's work in constructing the "I" as absent while placing it at the centre of the act of remembrance. Instead of placing herself in the film, Morley uses point-of view-shots in which only the gaze of the camera is represented. By constructing herself as an absence, the film's protagonist Carol Morley becomes the film's 'slip- 
pery signifier' exposing the patriarchal discourses which run through the recollections and in which Morley's sexual activity is pathologised while she is described as a 'freak'.

Morley's film reflects on the power structures involved in the mediation of the past. Who has the prerogative of definition over the past? Whose version will be circulated? The witness accounts do not represent a range of divergent memories, but they echo each other by constantly repeating patriarchal views on female sexuality. The film's feminist perspective foregrounds the construction of hegemonic cultural memory with its inherent male homosociality, its stereotypical representation of women as wives, girlfriends or groupies, and its heteronormative stance. Carol Morley's film defies from offering a "herstory" which would add yet another recollection of the past to the patriarchal "master narrative". Subverting conventional narrative schemata for stories of women in rock music, The Alcohol Years sets out to deconstruct hegemonic pop-historiography. In avoiding essentialist subject positions, the film addresses the modes of exclusion prevalent in post-punk historiography. It shows how cultural memory is constructed as a homosocial (male) sphere, marginalising norm-critical and non-heteronormative practices. Offering a place for both the enunciation of bisexuality and of non-normative female sexual behaviour, such as often changing sexual partners, the film carves out a discursive space for non-hegemonic articulations of sexuality.

The Alcohol Years is both an intervention into the audiovisual memories of the city and part of the retro culture around the memorialisation of 1980s Manchester. Morley's film defies dominant modes of visual representations of music culture which we find in band documentaries with their collage of talking heads and archival footage of the band's live performances. The Alcohol Years does not attempt to create an 'authentic look' at the past, trying to represent history "how it really was". Abstaining from the use of archival footage Morley employs contemporary footage of the Manchester city spaces, of rainy streets and night clubs on a Friday or Saturday night, thus linking the past and the present.

\section{Creating mnemotopes: remediation as place-making}

Memories are always on the move, both geographically (being reworked by global audiences) and by being adapted into a new discursive framework, e.g. that of the city's neoliberal regeneration politics. Despite its transnational mobility, the locality of cultural memory remains an important question for memory scholars. Although memory studies are currently turning from the sites of memory towards its dynamics, I deliberately choose the memory of a city because the memory of a place not only entails a geographical, but also a diachronic perspective, as it is mobilised within diverging discursive frameworks. This way of conceptualising the 
relation between space and mediated memories allows us to rethink Pierre Nora's notion of the 'lieux de mémoire', which is constructed, stabilised or renegotiated through a series of remediations (see Brunow 2015: 2-3). Nora's concept, however, has been criticised for its focus on the nation-state, its exclusion of migrant and diasporic experiences as well as for its lack of considering the role of media specificity in the creation of memory (see Brunow 2015: 2-3). Employing the notion of the 'mnemotope', derived from Bakhtin's concept of the chronotope (Bakhtin 1996) as an alternative to Nora's concept, this article looks at the ways cultural memory translates into different context in the same local space. Bakhtin conceptualises the chronotope as a spatial-temporal dimension which is artistically expressed. My ambition is not to engage with the vast research on Bakhtin, but to use his concept in a heuristic fashion.

Continuous remediation is a process of place-making through which certain mnemotopes are created. Travel guides, city tours, audio walks, tourist amateur photography or selfies in front of iconic buildings contribute to mapping the city. So does fan culture, such as uploads on YouTube or the practice of sharing digital memories of the city on Flickr or Instagram. Fan practice on the internet, for instance the sharing of photographs or videos, creates transnational digital memories which in turn contribute to urban mapping. They create a psychogeography of the city which eventually evolves into mnemotope. One example of such a remediation which shows how urban mapping and cultural memory are related is the case of the Salford Lad's Club. A photograph of The Smiths by Stephen Wright, which shows the band standing in front of the Salford Lad's Club, at the entrance to the red brick building, was used on the inner sleeve of the band's single "The Queen is Dead" in 1986 and has since achieved iconic status. A quick search on Google reveals innumerable amateur photographs of tourists and Smiths fans posing in front of the building, almost all of them imitating the camera angle of the original shot. The motif is so embedded within the cultural memory of his generation that even David Cameron tried to profit from its popularity by posing in front of the building during his election campaign before he became the British prime minister. Photographs, such as the amateur shots of the Salford Lad's Club or the legendary photographs by Kevin Cummins, published in the music press and on record sleeves during the late 1970s and 1980s, create an imaginary cartography of the city's urban spaces.

Not only visual culture has contributed to the mapping of the city - the same can be said for songs and their various remediations as well as narratives and mythmaking evolving around specific geographical places. Through such processes of remediation the audiovisual memory of post-punk Manchester has come to focus on specific sites or mnemonic nodal points. One of them is the legendary Haçienda, a nightclub and concert venue situated on Whitworth Street, which 
operated between 1982 and 1997. After its final closure in 1997 the Haçienda was torn down in 2002. Two years earlier 'memorabilia' from the Haçienda were auctioned off. Michael Winterbottom's film 24 Hour Party People contributed to the club's legendary status in 2002. In August 2007 an exhibition celebrated 25 years of the Haçienda. The club, musealised at the Manchester Museum of Science and Industry, also figures in Peter Hook's memoir The Haçienda. How Not to Run a Club (Hook 2009), and was recreated at the Victoria and Albert Museum for an exhibition of iconic British design in 2012. Different acts of remembrance and transmedia remediations have transformed The Haçienda into a mnemotope. For Pierre Nora, lieux de mémoires come into existence first when the original places disappear. While Nora's conceptualisation is rather static, I argue that the concept of 'mnemotope' allows us to look at the ways urban spaces are created through the mobilisation of cultural memory. A mnemotope, just as memory, is dynamic and continuously reworked according to the discursive frameworks guiding processes of remediation. By merging 1980s post-punk culture and 1990s rave culture (Madchester) the mediated cultural memories of the Haçienda turn it into a mnemotope. However, not only remediations, but also intermedial and intertextual references contribute to creating a mnemotope. For example, the club's name "The Haçienda" is an intermedial reference to Ivan Chtcheglov and his 1953 text "Formulary for a New Urbanism", which inspired the lettrists and the situationists. Different cultural practices are placed in a continuum encompassing time and space. In the case of naming the Haçienda, cultural distinction might have been one reason for the decision.

Perceiving oneself as culturally distinct from mainstream culture has been important for the self-fashioning of post-punk Manchester. Dave Haslam's account Manchester, England. The story of the pop cult city, originally published in 1999, is in itself part of the discourse on Manchester's rebirth after its industrial decline. $\mathrm{He}$ describes how Manchester has changed from an industrial to a creative city, from Cottonopolis to Madchester. In the introductory article "Manchester: Past Imperfect, Present Tense, Future Uncertain" Haslam anthropomorphises the city when stating:

Manchester, like England, is now re-creating itself, looking for a new role, a life without manufacturing industry. Like a middle-aged man made redundant after a lifetime in a factory, Manchester is either facing years drawing charity, welfare and government handouts, or it's going to retrain, reorganise, and find something to keep it occupied (Haslam 1999/2000: xi). 
Through this rhetorical device the city's transcultural complexity becomes unified and homogenised. According to Haslam, during the late 1980s the Madchester era's "thriving sub-culture" epitomised a crucial turning point for the rebuilding and refashioning of Manchester, symbolising that "the city was no longer carrying the baggage of a hundred and fifty years of preconceptions, about the weather, the environment, the misery. Manchester's talent [...] embodied an attitude which struck a chord worldwide" (Haslam 1999/2000: 250). In contrast, the city's official heritage politics of turning Castlefield into the UK's first "Urban Heritage Park" is described by Haslam as "death sentence heritage. It was as if we were all destined to no better future than re-creating a tourist version of the old days; Manchester as hygienic industrial theme park" (Haslam 1999/2000: 250). Of course, we have to read Haslam's statement as highly performative in the sense that he is trying to contribute to a new 'master narrative' of Manchester as the "pop cult city", as his book is subtitled. In his evaluation of the development he characterises official heritage politics as inefficient, while the true impulses for the city's redevelopment stem from its subcultures: "It has now become accepted that shopping and tourism have key roles in the future prosperity of the city. For the young, especially, Manchester is becoming a must-see city, a cult pop city, and it was probably the Madchester era that brought the first big influx of tourists" (Haslam 1999/2000: 254). For instance, a concert by The Stone Roses with an audience of almost thirty thousand drew people from the whole of Europe and overseas. While Haslam's book was written before the massive Manchester 'memory boom', it is interesting to see how the mnemotope of Manchester music city has been broadened out from 1990s Madchester to include late 1970s punk and 1980s post-punk. According to Redfern 24 Hour Party People depicts "the Manchester punk and rave scene as building on the city's proud history, and specifically demonstrates an awareness of this history. It seeks to build on a tradition of progressiveness that is projected as the antithesis of 'death sentence heritage"' (Redfern 2005: 303). Redfern describes 24 Hour Party People as "a nostalgic tour through the 'ripped backsides' of Hulme, Little Hulton, and Castlefield, and the film celebrates the marginal status of these places beyond London, but also beyond the official discourses of nostalgia and heritage in the North" (Redfern 2005: 300). While this celebration might be "beyond the official discourses" on a diegetic level (within the film's universe), 24 Hour Party People, just like Control, ties into politics of city branding in the context of urban reconstruction. The memory culture of post-punk Manchester is multidirectional indeed, as the next section will illustrate. 


\section{Mobilising post-punk memory for the city's culture-led regeneration}

Manchester's past fame as an industrial city declined gradually from the 1960s to the 1980s. Ironically enough, the IRA bombing in 1996, devastating great parts of the city centre, created new opportunities for city planning. Since the mid-1990s huge investments have been made and cultural attractions led to an increase in tourism.

The narrative formula used in relaunching the city shifted the emphasis from industrial to urbanistic innovation, employing popular culture as a symbol of vibrancy and creativity. It is based on long-standing narratives of Manchester as the first global city, as entrepreneurial and open to change (O'Connor \& Wynne 1996). In order to coordinate such efforts the agency 'Marketing Manchester' was founded, a private-public partnership of the City Council and Manchester Airport (Haslam 1999/2000), aiming to attract investors and tourists. In 2004 Peter Saville, co-founder of Factory Records, who had designed the iconic record covers for Joy Division and New Order, became the creative director of the City of Manchester. Saville's tasks included the conceptualisation of international exhibitions and festivals, the city's cultural strategy and the design for Metrolink. As Guy Julier maintains, "Saville is implicated into the mythology of Manchester's most-known popular cultural history" (Julier 2005: 882). In the same year, in 2004, a retrospective of Peter Saville's works was showcased in the exhibition space Urbis which was part of the regeneration project in the aftermath of the 1996 IRA bombing. "Saville's hand is deployed across the city's designscape, not just through the Urbis exhibition but, for example, through his historical association with Factory Records, to inflect this tradition of modernity with the desired notions of 'attitude' and 'edge", Julier sums up (2005: 882). This personal continuity from post-punk Manchester to contemporary city branding is also epitomised in Tony Wilson, founder of Factory Records and the Haçienda, who was a board member of "Elevate East Lancashire", "one of the government's 'market renewal' agencies" (Minton 2009: 37).

Subcultural memories have been mobilised in Manchester's culture-led regeneration. Independent culture, ultimately commodified, has been incorporated into neoliberal ideas of the creative city, as launched prominently by Richard Florida (2002) in his The Rise of the Creative Class. According to Florida, in the first decade of the new millennium Manchester became the most creative and enterprising city in the UK (Minton 2009: 39). Another potential factor in city branding is fan culture. Even if individual fans might oppose gentrification, fan culture is complicit in neoliberal politics of culture-led regeneration. Fan culture involves a number of place-making projects which contribute to the mapping of urban space. City walks and tours visit sites and locations which played a role in the his- 
tory of Manchester's music scene (Gatenby \& Gill 2011). Until his death in 2016, Inspiral Carpets drummer Craig Gill offered tours promoted by the official website for Manchester tourism. ${ }^{9}$ His company, Manchester Music Tours, nominated for The Tourism Star award (Manchester Tourism Awards 2012), was founded in $2005 .{ }^{10}$ What had initially had started as a walking tour to significant sites of the local music scene developed into five driving tours, four of them centring on individual bands (The Smiths, Joy Division, Oasis, The Stone Roses), while a fifth is dedicated to the label Factory Records. Fan culture, triggered by nostalgia and 'retromania', both relocates cultural memories in the city space, but also dislocates or deterritorialises them. Remediated transcultural memories oscillate between locatedness and deterritorialisation. This oscillation is characteristic for digital memories.

These findings underline the need to rethink the notion of space as culturally constructed and therefore as a product of cultural memory. Space is not just "out there", waiting to be mediated and memorialised, but it is constructed through a variety of place-making projects. Manchester's brand identity could profit from the "subcultural city branding" conducted via the self-fashioning of 1980s postpunk culture. As Redfern points out, Manchester developed its "own cultural networks with the creation of independent record labels, fanzines, and venues that deliberately steered clear of the mainstream, and, in doing so, created a powerful voice for those outside London" (Redfern 2005: 289). London was "associated with an artistic conservatism and political Conservatism that Manchester subverts" (Redfern 2005: 299-300). ${ }^{11}$ Manchester's culture-led urban regeneration draws on long-standing narrative formula which premediate future remediations. The North (of England) has become a mnemotope through longue durée processes and transmedia networks of cultural memory, from Elizabeth Gaskell's novel North and South via the works of the "Angry Young Men", the 1950s working-class writers in the Northwest, to the television series Coronation Street and 24 Hour Party People. Such overlapping intermedial references, layered like a palimpsest and encompassing different geographical spheres, provide narrative schemata for future remediations. Such 'premediations' (Grusin 2004, Erll 2009) were tropes of 'Northernness', based on the North-South-divide. Drawing on these discourses in the process of city branding allowed Manchester, as Redfern (2005: 290) states, "to re-create itself as an innovative centre of culture that was modernising and forward-looking rather than provincial." The premediations were reworked, and the notion of 'Northernness', for example, "was refracted through an avant-gardism to create not a nostalgic view of the North as 'working-class', but as [...] 'working-class bohemianism"' (Redfern 2005: 290-291). This interaction of premediation and remediation shows how certain narrative templates are used, but instead of remaining unchanged and stable, they are reworked in the process of 
remediation. At the same time these premediations contribute to mapping the region and function as a method of place-making.

Just like other media such as photography, travel writing, biographies or songs, filmmaking is a method of place-making. In 24 Hour Party People Manchester is represented as a cultural region, Redfern argues, associated "with new cultural spaces in the city that develop free of the centralising influences of the London-based music industry, and where the distinction between producers and consumers of cultural products is blurred" (Redfern 2005: 287). In contrast, The Alcohol Years does not contribute to place-making projects which can be employed for contemporary city planning. The contemporary footage employed in the film does not evoke the iconic images of Manchester constantly remediated in a plurality of media. Instead, the Mancunian street scenes could easily take place anytime and anywhere and point at the contemporary relevance of the film's feminist criticism: nothing seems to have changed.

\section{Manchester: Queering (sub)cultural memory and loca- ting LGBT+ memories}

While not much seems to have changed when it come to the representation of gender, the representation of sexuality in the cultural memory of the city has moved on to some degree. Manchester illustrates a trend within city planning in which previously marginalised LGBT+ memories are being employed in city branding. According to Richard Florida (2002) creativity and a good 'gay index' prove fertile ground for the city's economic growth. A gay index indicates "an area's openness to different kinds of people and ideas" (Florida 2002: 255-258). Despite Manchester's fame as the "gay capital of the North", the cultural memory of the city's queer past has long been absent from the locations associated with post-punk memory, such as the Haçienda. In 1984 the Haçienda hosted a benefit for Lesbians and Gays Support the Miners. In the Gay Traitor Bar, housed in the cellar, the Gay Monday Nights, which started in 1985, attracted busloads of queers from the wider region, its slogans "Queer as Fuck" and "Practice makes Pervert" being advertised citywide. And although the nightclub "Flesh" at the Haçienda played a pioneering role for Manchester's LGBT+ culture, queer cultural memory is not located around the iconic post-punk spaces. Instead, in the memory of the city, LGBT+ memories have long been relegated to the Canal Street area, which has become immensely popularised (and mainstreamed) through TV series such as Bob and Rose (ITV 2001) and Queer as Folk (Channel 4, 1999-2000, since then also remade into a US version). This was not always the case: during the 1980s the former red-light district around Canal Street was under immense surveillance by the police. The attitude towards the area's queer culture changed first during the 
1990s when Canal Street was acknowledged as a tourist attraction by Manchester City Council.

It seems that the discourse on "Gaychester" within Manchester's post-punk memory had narrowed down during the first decade of the millennium before opening up again only a couple of years ago. While in his 1999 book Manchester England Haslam (1999/2000: 199-201) briefly mentions the resurgence of a gay scene in the early 1990s, it then seems to have gradually disappeared from the city's subcultural memory for over a decade. Only recently memory projects of queer Manchester surfaced. In 2013 the Museum of Science and Industry, which also owns the archive of Factory Records, showcased the community exhibition "Behind the Scene; Stories from Manchester's LGBT Communities". In 2016, the People's Museum in Manchester housed an exhibition on the city's LGBT+ history. Meanwhile, the Manchester Digital Music Archive (MDMarchive), an online community archive established in 2003, sets out to highlight previously hidden narratives through exhibitions, panels and educational work, thus working towards diversifying the cultural memory of the city. Its most recent project "Rebel Music: The Sound of Politics and Protest in Manchester", launched in 2017, dedicates itself to the musical achievements of women and the queer community. The online exhibition 'Queer Noise' collects memorabilia and oral histories of LGBT+ persons. ${ }^{12}$ In addition, a physical exhibition, "Queer Noise: The History of LGBT+ Music \& Club Culture in Manchester" was held at the People's History Museum in 2017. Another example of the archive's intersectional approach was the panel 'Black Female Voices', hosted in 2018 as part of the "Rebel Music"-project. These events and exhibitions are interventions into Manchester's homosocial memory culture. However, the case of the MDMarchive also points at the vulnerability of queer memory work as voluntary-run projects and institutions would require long-term funding to be sustainable. The example shows the power imbalances at work within different stakeholders' engagement with the past.

\section{Conclusion: transcultural memories in urban spaces}

Outlining the memory boom around post-punk Manchester allows us to critically examine whose heritage is constructed and to analyse which stories are included - or excluded. If we regard cultural memory as a "field of cultural negotiation through which different stories vie for a place in history" (Sturken 1997: 1), we can observe a tendency that the stories are actually not as different as it might seem. Diversity has long been lacking in the cultural memorialisation of 1980s postpunk Manchester. What at first glance appears to be a myriad of accounts is less polyvocal than it looks, despite its style or genre. Until recently the cultural memory of 1980 s post-punk has had the tendency to close rather than open up any 
discursive spaces for the articulation of memories by feminists, queers or Black or Asian Britons. Carol Morley's essay film The Alcohol Years (2000) foregrounds the construction of cultural memory by revealing which discursive spaces are opened and which are closed in the processes of remembrance. Just like the work of the MDMarchive, her film is an intervention into the audiovisual memories constantly being reworked around Manchester's post-punk heritage.

This article has shown how the notion of 'transcultural memories' can be used beyond realms of ethnicity and/or the nation. Not only is transcultural memory mobile in a geographical sense, but it is also constructed by different discursive frameworks. Transcultural memories are mobilised in different, albeit often overlapping, manners for various purposes and in a number of contexts: as forms of nostalgia, retro culture, as generational memory (plus personal memory and communicative memory), as 'official' memory in the context of city branding, as cultural memory connected to specific urban spaces. The dynamics of transcultural memory challenge the division between "official" and "subcultural" or "counter"-memory. The case study has discussed how different stakeholders invest in Manchester's subcultural histories. It has shown that subcultural memories are not emancipatory per se.

The mobility of transcultural memory should not be perceived as a linear or even teleological process. Memories are multidirectional. Cultural practice, once perceived as oppositional or alternative, is never fixed and stable, but can be translated and appropriated for a variety of purposes. Post-punk memory was not initially a subcultural phenomenon which then entered the mainstream. Instead both developments coincided, creating a tension in which Manchester's post-punk memory culture would engage with the discourse of urban regeneration in various ways. The example of such commodification of subcultural aesthetics and memory shows that popular memories are not automatically subversive, but can become part of a city's neoliberal regeneration politics by being incorporated into the local heritage industry. In view of Richard Florida's notion of the 'gay index' one might even find the neoliberal discourse more open to the inclusion of LGBT+ memories than the subcultural independent discourse which excludes or marginalises female and queer participants. While LGBT+ memories are only slowly carving out some discursive space in Manchester's post-punk memory culture, they have been smoothly mobilised for city branding.

The notion of "a warm blanket of acceptance and appreciation" (Reynolds 2011: 7) pervades the ways memories have been employed in the context of culture-led regeneration. Internal conflicts and structural power relations are set aside in favour of creating a narrative of consent. While circulating within different transcultural frameworks, Manchester's post-punk memories have been sanitised, fabricating consensus instead of celebrating difference. 
Dagmar Brunow is a senior lecturer in film studies at Linnaeus University, Sweden. Her research interests include media memory, film archives, video collectives and feminist filmmaking. She is the author of Remediating Transcultural Memory (Berlin/Boston, 2015) and editor of Stuart Hall. Aktivismus, Pop \& Politik (Mainz: 2015). Current research project: 'The Cultural Heritage of Moving Images' (Swedish Research Council 2016-2018). E-mail: dagmar.brunow@lnu.se

\section{Notes}

${ }^{1}$ This article is a revised and updated version of chapter 3.2. in my book Remediating Transcultural Memory (Brunow 2015).

2I will also leave out the songs themselves, whose self-reflexivity and intertextuality also includes an important memory dimension.

${ }^{3}$ If we perceive 'culture' as including multiple cultural practices, as this study does, the notion of 'subculture' is obsolete. However, as a discursive construct it can be the object of research.

${ }^{4}$ While the memory boom seems to have started by the end of the 1990s, tendencies for a memorialisation of post-punk Manchester were already initiated by Factory Records in the late 1970s. In 1979, on 13 September, Factory Records announced a film event at the now legendary Scala Cinema at King's Cross in London. The event, which was catalogued as FAC9, included $8 \mathrm{~mm}$ footage of Joy Division. On the label's information sheet the screening was announced as an "hommage [sic!] to the already golden age." (http://factoryrecords.org/factory-records/fac-9-various-artists-factoryflick.php (8 December 2017)

${ }^{5}$ Both the Haçienda (FAC 51) and 24 Hour Party People (FAC 451) were issued with Factory Records' catalogue numbers.

${ }^{6}$ For a more detailed discussion of 24 Hour Party People see Brabazon 2005, Redfern 2005 and Barton 2012.

${ }^{7}$ Moreover, Vini Reilly, the singer of The Durutti Column, was edited out of the film (Redfern 2005: 296). No matter what his sexual preferences might have been, Reilly's gender performance could permit a 'queer reading' since he performs a more effeminate version of masculinity which is highly different from that of the other male characters in the film. His presence in the film would have challenged the representation of male homosociality in 24 Hour Party People.

${ }^{8}$ For a more detailed analysis of The Alcohol Years, see Brunow 2015: 83-89.

${ }^{9}$ http://www.visitmanchester.com/articles/video/craig-gill-mcr11-interview/ (8 June 2014).

${ }^{10}$ http://www.manchestermusictours.com/ (8 June 2014).

${ }^{11}$ This development could be observed in other cities as well, such as Liverpool and Coventry, for example.

${ }^{12}$ http://www.mdmarchive.co.uk/exhibition/id/77/QUEER NOISE.html (8 December 2017). 


\section{Culture Unbound}

Journal of Current Cultural Research

\section{References}

The Alcohol Years, (2000): [DVD], Carol Morley, UK: Ace Visual Art/Arts Council of England/Cannon and Morley Productions/London Production Fund.

Bakhtin, Mikhail M. (1996): "Forms of Time and of the Chronotope in the Novel", Michael Holquist (ed.): The Dialogic Imagination: Four Essays by M.M. Bakhtin, Austin: University of Texas Press, 84-258.

Barton, Joe (2012): "Welcome to Manchester": Heritage, Urban Regeneration, and Michael Winterbottom's 24 Hour Party People', Frames Cinema Journal 2.

Bodnar, John (1992): Remaking America: Public Memory Commemoration and Patriotism in the Twentieth Century. Princeton: Princeton University Press

Bolter, Jay David \& Grusin, Richard (2000): Remediation: Understanding New Media, Cambridge, Mass.: MIT Press.

Bottà, Giacomo (2009): 'The city that was creative and did not know. Manchester and popular music, 1976-97', The European Journal of Cultural Studies, 3, 349-365.

Brabazon, Tara (2005): From Revolution to Revelation: Generation X, Popular Memory and Cultural Studies, Ashgate, Aldershot.

Brunow, Dagmar (2015): Remediating Transcultural Memory: Documentary Filmmaking as Archival Intervention, Berlin, Boston: de Gruyter.

Clarke, Dylan (2003): 'The Death and Life of Punk, the Last Subculture', David Muggleton and Rupert Weinzierl (eds): The Post-Subcultures Reader. Oxford: Berg, 223-36.

Cohen, Sara (2007): Decline, Renewal and the City in Popular Music Culture: Beyond the Beatles, Aldershot: Ashgate.

Cummins, Kevin (2009): Manchester: Looking for the Light through the Pouring Rain, London: faber and faber.

Curtis, Deborah (2007): Touching from a Distance: Ian Curtis and Joy Division, London: faber and faber.

DeCesari, Charia and Ann Rigney (eds)(2014): Transnational Memory: Circulation, Articulation, Scales, Berlin, Boston: de Gruyter.

Erll, Astrid (2008): 'Literature, Film, and the Mediality of Cultural Memory', Astrid Erll \& Ansgar Nünning (eds): Cultural Memory Studies: An International and Interdisciplinary Handbook, Berlin, New York: de Gruyter, 389-398.

Erll, Astrid (2009): 'Remembering across Time, Space and Cultures: Premediation, Remediation and the "Indian Mutiny", Astrid Erll and Ann Rigney (eds): Mediation, Remediation, and the Dynamics of Cultural Memory, Berlin, New York: de Gruyter, 109-138.

Erll, Astrid (2011): 'Travelling Memory', Parallax 17:4, 4-18.

Florida, Richard (2002): The Rise of the Creative Class, New York: Basic Books.

Foucault, Michel (1975): 'Film and Popular Memory', An Interview with Michel Foucault, Radical Philosophy 11, 24-29.

Gatenby, Phill \& Craig Gill (2011): The Manchester Musical History Tour, Manchester: Empire Publications.

Grusin, Richard (2004): 'Premediation', Criticism 46:1, 17-39.

Hall, Stuart (2002): "Whose Heritage? Un-settling 'The Heritage', Re-imagining the Post-Nation", Rasheed Araaen, Sean Cubitt \& Ziauddin Sardar (eds): The Third Text Reader on Art, Culture and Theory, London, New York: Continuum, 72-84

Haslam, Dave (1999/2000): Manchester England: The Story of the Pop Cult City, London: Fourth Estate.

Hebdidge, Dick (1979/1996): Subculture: The Meaning of Style, London, New York: Routledge.

Hook, Peter (2009): The Hacienda: How Not to Run a Club, London: Simon \& Schuster.

Hook, Peter (2013): Unknown Pleasures: Inside Joy Division, London: Simon \& 


\section{Culture Unbound}

Journal of Current Cultural Research

Schuster.

Julier, Guy (2005): 'Urban Designscapes and the Production of Aesthetic Consent', Urban Studies, 42:5/6, 869-887.

Landsberg, Alison (2004): Prosthetic Memory: The Transformation of American Remembrance in the Age of Mass Culture. New York, NY: Columbia University Press.

Lipsitz, George (1990): Time Passages: Collective Memory and American Popular Culture. Minneapolis: University of Minnesota Press.

Middles, Mick (1996/2002): From Joy Division to New Order: The True Story of Anthony H. Wilson and Factory Records, London: Virgin Books.

Middles, Mick (2009): Factory: The Story of the Record Label, London: Virgin Books.

Minton, Anna (2009): Ground Control: Fear and Happiness in the Twenty-First-Century-City, London: Penguin

Morley, Paul (2008): Joy Division: Piece by Piece, London: Plexus.

Nice, James (2010): Shadowplayers: The Rise and Fall of Factory Records, London: Aurum Press.

Nora, Pierre (ed.) (1984-92): Les lieux de mémoire, 3 vols, Paris: Gallimard.

O'Connor, Justin and Derek Wynne (eds) (1996): From the Margins to the Centre: Cultural Production and Consumption in the Post-Industrial City, Aldershot: Arena.

Reade, Lindsay (2010): Mr Manchester and the Factory Girl: The Story of Tony and Lindsay Wilson, London: Plexus Publishing.

Redfern, Nick (2005): “We do things differently here": Manchester as a Cultural Region in 24 Hour Party People.' EnterText 5:2, 286-306.

Reynolds, Simon and Joy Press (1995): The Sex Revolts: Gender, Rebellion and Rock'n'Roll, London: Serpent's Tail.

Reynolds, Simon (2011): Retromania: Pop culture's addiction to its own past, London: faber and faber.

Rigney, Ann \& Erll, Astrid (2009): 'Introduction: Cultural Memory and Its Dynamics', Astrid Erll \& Ann Rigney (eds): Mediation, Remediation, and the Dynamics of Cultural Memory, Berlin: de Gruyter, 1-11.

Robb, John (2006): Punk Rock: An Oral History, London: Ebury Press.

Robb, John (2010): The North Will Rise Again: Manchester Music City 1976-1996, London: Aurum Press.

Roberts, Les (2014): 'Talkin bout my generation: popular music and

the culture of heritage', International Journal of Heritage Studies, 20:3, 262-280.

Roberts, Les and Sara Cohen (2014): Unauthorizing popular music heritage: outline of a critical framework. International Journal of Heritage Studies 20:3, 241-261.

Rothberg, Michael (2009): Multidirectional Memory: Remembering the Holocaust in the Age of Decolonization, Stanford: Stanford University Press.

Sedgwick, Eve Kosofsky (1985): Between Men: English literature and male homosocial desire, New York: Columbia University Press.

Sturken, Marita (1997): Tangled memories: the Vietnam War, the AIDS epidemic, and the politics of remembering, Berkeley: University of California Press.

Thornton, Sarah (1997): 'The Social Logic of Subcultural Capital', Ken Gelder \& Sarah Thornton (eds): The Subcultures Reader, London, New York: Routledge, 200-209.

Wilson, Tony (2002): 24 Hour Party People: What the Sleeve Notes Never Tell You, London: 4 Books. 